\title{
The Microbial Habitability of Weathered Volcanic Glass Inferred from Continuous Sensing Techniques
}

\author{
Elizabeth A. Bagshaw, Charles S. Cockell, ${ }^{2, \star}$ Naresh Magan, ${ }^{3}$ Jemma L. Wadham,, T. Venugopalan, ${ }^{4}$ \\ Tong Sun, ${ }^{4}$ Matt Mowlem, ${ }^{5}$ and Anthony J. Croxford ${ }^{6}$
}

\begin{abstract}
Basaltic glasses (hyaloclastite) are a widespread habitat for life in volcanic environments, yet their interior physical conditions are poorly characterized. We investigated the characteristics of exposed weathered basaltic glass from a surface outcrop in Iceland, using microprobes capable of continuous sensing, to determine whether the physical conditions in the rock interior are hospitable to microbial life. The material provided thermal protection from freeze-thaw and rapid temperature fluctuations, similar to data reported for other rock types. Water activity experiments showed that at moisture contents less than $13 \%$ wet weight, the glass and its weathering product, palagonite, had a water activity below levels suitable for bacterial growth. In pore spaces, however, these higher moisture conditions might be maintained for many days after a precipitation event. Gas exchange between the rock interior and exterior was rapid $(<10 \mathrm{~min})$ when the rocks were dry, but when saturated with water, equilibration took many hours. During this period, we demonstrated the potential for low oxygen conditions within the rock caused by respiratory stimulation of the heterotrophic community within. These conditions might exist within subglacial environments during the formation of the rocks or in microenvironments in the interior of exposed rocks. The experiments showed that microbial communities at the site studied here could potentially be active for 39\% of the year, if the depth of the community within the outcrop maintains a balance between access to liquid water and adequate protection from freezing. In the absence of precipitation, the interior of weathered basaltic glass is an extreme and life-limiting environment for microorganisms on Earth and other planets. Key Words: Basaltic glass-Palagonite-Oxygen sensing-CryptoendolithsLife in extreme environments. Astrobiology 11, 651-664.
\end{abstract}

\section{Introduction}

T HE INTERIOR of surface-exposed rocks is known to be an extreme environment for life (Friedmann, 1980; Bell, 1993; de la Torre et al., 2003; Walker and Pace, 2007). In particular, fresh rocks, such as those produced by volcanic eruptions, have low concentrations of organic carbon; and unless the rocks are subjected to extremes of $\mathrm{pH}$ or high water flow, the leaching of nutrients from the rock matrix itself will be slow and limit the availability of major cations and other elements required by life (Gomez-Alvarez et al., 2007).

Understanding the physical and chemical conditions in rock interiors is important for gaining an insight into the factors that control the microbial habitability of rocky envi- ronments on this planet and in more extreme extraterrestrial settings. In turn, these data have implications for Earth sciences, including elucidation of (1) the potential role of biota in rock weathering (which influences long-term climate through the consumption of $\mathrm{CO}_{2}$ in rock weathering reactions) and (2) the extent to which newly formed or exposed rocks can provide a substrate for the establishment of carbon and nitrogen cycles, which support further succession for both microbial communities and higher (animal and plant) communities.

Of particular interest are volcanic rocks. Approximately $30 \%$ of the total global carbon dioxide drawdown in weathering reactions is attributable to volcanic (basaltic) rocks, and their chemical weathering behavior is well

\footnotetext{
${ }^{1}$ Bristol Glaciology Centre, School of Geographical Sciences, University of Bristol, Bristol, UK.

${ }^{2}$ CEPSAR, Open University, Milton Keynes, UK.

${ }^{3}$ Cranfield Health, Cranfield University, Cranfield, UK.

${ }^{4}$ School of Engineering and Mathematical Sciences, City University, London, UK.

${ }^{5}$ National Oceanography Centre, University of Southampton, Southampton, UK.

${ }^{6}$ Queens School of Engineering, University of Bristol, Bristol, UK.

*Present address: SUPA, School of Physics and Astronomy, University of Edinburgh, Edinburgh, UK.
} 
studied (Dessert et al., 2003). Microorganisms are known to contribute to weathering processes on volcanic rocks (Adamo et al., 1993). Successional changes in volcanic rocks have been documented; for example, pioneer algae colonized the basaltic rocks on Surtsey, Iceland, following the islandforming eruption that began in 1963 and ended in 1967 (Schwabe, 1972; Brock, 1973; Broady, 1982). However, the conditions within volcanic rocks in which pioneer microorganisms must establish themselves and the long-term conditions that established microbial communities experience are not well characterized. Studies have so far been focused on the organisms and their imaged micro-environments (Etienne and Dupont, 2002; Herrera et al., 2009) but not on the physical conditions within the rock itself.

One common product of volcanic eruptions is basaltic glass, which is produced when lava of basaltic composition comes into contact with ice or water and quenches to form a glass that is subsequently altered to the aqueous weathering product, palagonite (Stroncik and Schmincke, 2002). Aqueous environments are common in locations where volcanic eruptions occur, so that basaltic glass is also a very common material in volcanic regions (Jacobsson and Gudmundsson, 2008). Basaltic glass is known to host diverse microbial communities in the deep ocean (Thorseth et al., 2001; Lysnes et al., 2004; Mason et al., 2007; Santelli et al., 2008), and only recently has the diversity of volcanic glasses been studied in terrestrial environments (Cockell et al., 2009a, 2009b; Herrera et al., 2009; Kelly et al., 2010). In Iceland, the surface and nearsurface of the rocks host phototrophs, while the surface and interior of the rocks host a high diversity of sequences associated with heterotrophs, including Actinobacteria and Proteobacteria. This suggests that organic carbon, either exogenous or produced by the resident photoautotrophic population, drives much of the active bacterial community (Cockell et al., 2009b).

Basaltic glass is of astrobiological interest. On any planet where molten rock comes into contact with water, particularly in glacial environments, glass will be formed. Glacial deposits or landforms associated with them have been observed on Mars in the form of ice-rich and glacierlike flows, ice-rich dust mantles, and patterned ground (Head and Marchant, 2003). In the past, active volcanism would have brought basaltic lava into contact with water there and produced basaltic glass. Basaltic glass and palagonite have been reported by remote sensing (Allen et al., 1981; Michalski et al., 2005; Ruff et al., 2006; Hamilton et al., 2008; Laan et al., 2009). However, assessing whether this is appropriate material to seek evidence of past life in surface or near-surface environments depends on an assessment of its interior habitability.

Although there have been studies on the microbial diversity of basaltic glasses in which culture and cultureindependent methods were used, we do not know what conditions these organisms experience within the rock and how extreme the rock environment is, particularly in exposed surficial outcrops where water availability may be intermittent. Some fundamental questions remain unanswered that have a direct bearing on the conditions for the interior microbial communities. These questions include the following: What is the water retention capacity of weathered basaltic glasses? Do weathering products, such as palagonite, retain sufficient water to act as a substrate for microbial growth during dry periods? How rapid is gas exchange from the interior to the exterior of the rock-if the rocks are saturated with water can they become anaerobic as a result of respiratory consumption of $\mathrm{O}_{2}$ ?

There have been some attempts to quantify conditions in the interior of basaltic glass in the field (Fisk et al., 1998; Cockell et al., 2010), but few systematic laboratory assessments of the degree of linkage between locations in the rock that are likely microbial habitats and the exterior environment. This is of particular interest in environments that are classed as "extreme" habitats for life, including areas where organisms are subjected to extreme temperatures, desiccation, biogeochemical conditions, radiation exposure, and other similar physical constraints. In the present study, we carried out an investigation of the conditions for life within basaltic glass from Iceland by implanting continuously monitoring microsensors into a rock sample. This novel technique aims to assess the conditions in the interior of the rock and to assess how changes in external conditions (e.g., temperature, rainfall) might have the potential to alter the rock internal environment. We report combined observations on porosity, water activity, temperature, relative humidity, and $\mathrm{O}_{2}$ regimen; and we discuss the implications for basaltic glass as a novel extreme environment for microbial life.

\section{Materials and Methods}

\subsection{Samples}

Samples of weathered basaltic glass were collected from near the Hekla volcano in southern Iceland $\left(66^{\circ} 4.83^{\prime} \mathrm{N}\right.$, $19^{\circ} 32.53^{\prime} \mathrm{W}$, Fig. 1C). The Sedgwick outcrop is of Pleistocene age ( $<0.8 \mathrm{Ma}$ old) and forms exposed outcrops throughout the study area (Fig. 1C) as a result of subglacial eruptions (Jacobsson and Gudmundsson, 2008). The rock material is a typical mixture of basaltic glass and its weathering product, palagonite (Cockell et al., 2009a). The palagonite forms rinds of uniform thickness on the weathered glass surface of $\sim 10 \mu \mathrm{m}$ thickness throughout the rock interstices (Fig. 1A, 1B). The microbial population is thus primarily located on palagonite surfaces (Cockell et al., 2009b). The rock sample used in the laboratory experiments was approximately $16 \times 12 \times 12 \mathrm{~cm}$ (Fig. 1).

\subsection{Field data}

Temperature was monitored at different depths in a basalt outcrop at the field site by a network of thermocouples. They were placed on the outcrop surface and below 2, 10, and $20 \mathrm{~cm}$ of rock in order to monitor the influence of external temperature conditions upon internal rock temperatures. Temperature at $2 \mathrm{~cm}$ depth was measured by drilling a hole into the underside of a rock sample and placing the thermocouple within the rock. Temperatures at 10 and $20 \mathrm{~cm}$ depth were measured by feeding the thermocouple through a small fracture in an outcrop until the stated depth was reached. The fracture may have slightly different heat transfer characteristics to the porous rock matrix but was preferable to drilling an additional hole to insert the temperature probes. Air temperature was also monitored. Readings were taken hourly $(10 \mathrm{~cm}$ ) or every $15 \mathrm{~min}$ (air, 2 and $20 \mathrm{~cm}$ ) for $1-3$ years. Precipitation data for the same time period was obtained from a network of meteorological stations operated by the Icelandic Meteorological Office. 


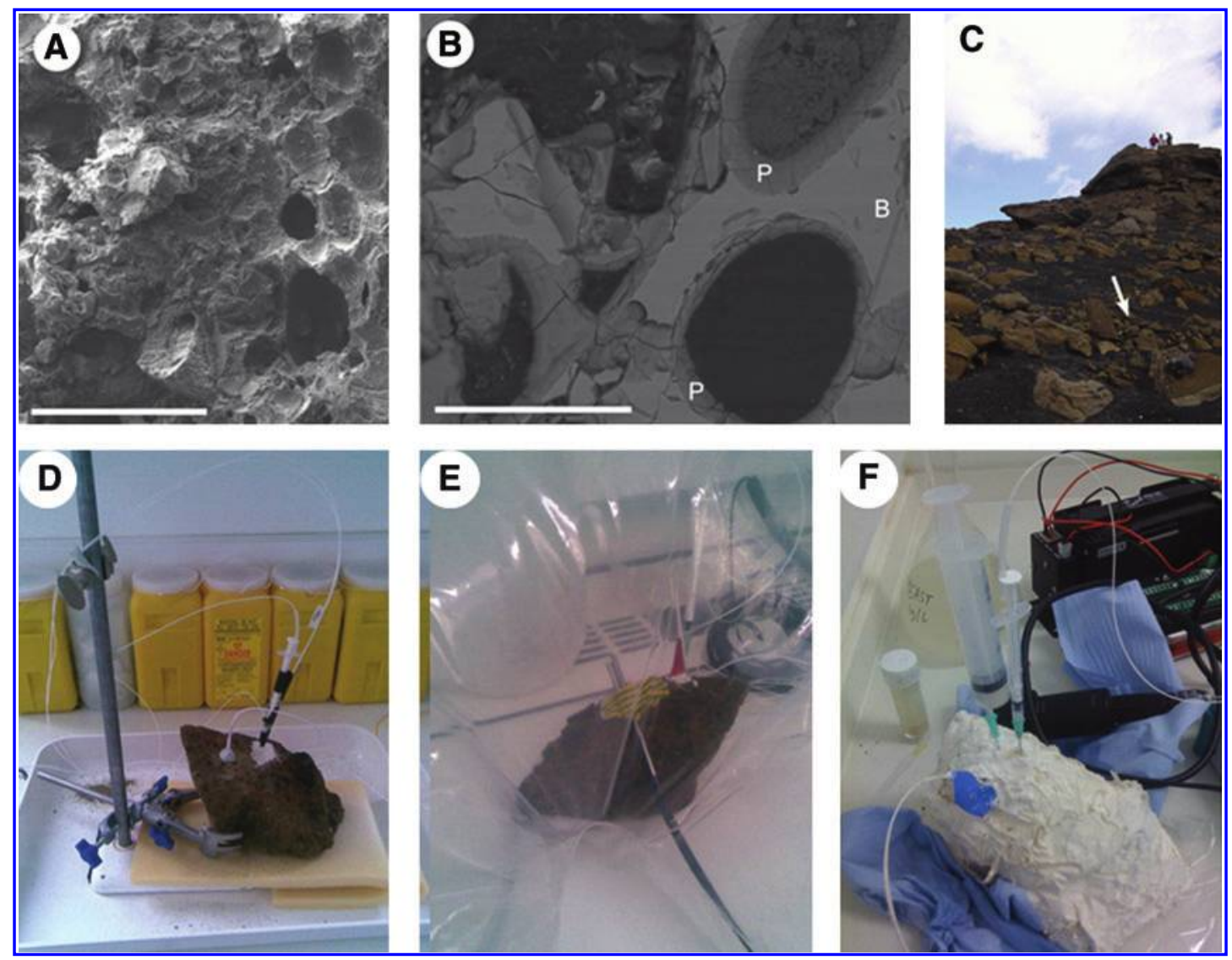

FIG. 1. (A) Secondary electron image showing the vesicular pore space (scale bar $=500 \mu$ m); (B) backscattered image showing the basaltic glass vesicles $(\mathrm{B})$ and layer of palagonite $(\mathrm{P})$ resulting from basaltic glass weathering $(\mathrm{scale} b a r=100 \mu \mathrm{m})$; (C) the field outcrop, with the white arrow showing where the rock sample was collected; (D) oxygen, temperature, and humidity monitoring with interior fiber optic probes; (E) oxygen and temperature sampling with interior and exterior probes in a $\mathrm{N}_{2}$ gas atmosphere; $(\mathrm{F})$ oxygen and temperature monitoring with interior probes during yeast substrate injection, with a sealed surface preventing contact with the atmosphere. Color images available online at www.liebertonline.com/ast

\subsection{Porosity and surface area}

The surface area of the material was determined by Brunauer-Emmett-Teller (BET) analysis (five point) (Imperial College, London, UK) (Brunauer et al., 1938) in which small $\left(\sim 3 \mathrm{~mm}^{3}\right)$ fragments of material were used. The porosity of the material was determined by mercury intrusion porosimetry (MCA Services, Meldreth, Cambridge, UK). For both BET analysis and mercury intrusion porosimetry, fragments of rock pooled from six different samples were examined.

\subsection{Oxygen measurements}

The rock sample was subjected to a number of laboratory tests designed to mimic in situ field conditions. Probes to monitor oxygen, temperature, and humidity were fixed into the rock at a depth of $3 \mathrm{~cm}$ below the surface (Fig. 1D-F). Oxygen partial pressure in the gas phase or oxygen concentration in water (depending on whether the probe was in contact with liquid water or gas) and temperature were monitored by a PreSens Microx system (www.presens.de, Regensburg, Germany), which consists of an optical interrogator unit and an optical indicator mounted at the cleaved distal end of a $140 \mu \mathrm{m}$ silica optical fiber contained in a syringe tip. The indicator includes an immobilized ruthenium dye that exhibits fluorescence, which is quenched in the presence of oxygen (Klimant et al., 1995). The degree of quenching and hence oxygen concentration is determined by the interrogation unit, which measures the fluorescence decay time (Draxler et al., 1995; Demas et al., 1999). The response of this fluorescence lifetime indicator to variable dissolved oxygen concentration is governed by the SternVolmer equation (Eq. 1).

$$
\frac{\tau_{0}}{\tau}=1+K_{\mathrm{sv}}\left[\mathrm{O}_{2}\right]
$$

where $K_{\mathrm{sv}}$ is the Stern-Volmer constant, $\mathrm{O}_{2}$ is oxygen partial pressure, $\tau_{0}$ is lifetime of fluorophore in absence of oxygen, and $\tau$ is lifetime of the fluorophore in presence of oxygen (PreSens, 2006).

The interrogator unit uses a phase modulation technique to evaluate the fluorescent decay time of the indicator material. The phase angle shift between the exciting and emitted light signals is a function of the oxygen partial pressure. The relationship between the measured phase angle $(\Phi)$ and oxygen concentration $\left[\mathrm{O}_{2}\right]$ is described by Eq. 2, where $\Phi_{0}$ is the phase angle of oxygen-free water.

$$
\left[\mathrm{O}_{2}\right]=\frac{\frac{\tan \Phi}{\tan \Phi_{0}}-1}{K_{\mathrm{sv}}}
$$


Salinity and temperature corrections are applied (PreSens sensors have an additional external temperature probe), and oxygen concentration is calculated by using a two-point calibration, which generates the $K_{\mathrm{sv}}$ constant at varying temperatures.

\subsection{Temperature measurements}

Temperature was monitored simultaneously to oxygen by the Microx temperature probe, which consists of a thermistor housed in a $2 \mathrm{~mm}$ diameter steel sheath, attached to a $140 \mu \mathrm{m}$ fiber. Phase angle, temperature, and the predicted oxygen saturation or concentration (percent air saturation or milligrams per liter) were logged on a PC by the Microx Oxyview software. When the rock was exposed to cold temperatures or left for more than $24 \mathrm{~h}$, temperature and oxygen were instead logged by a Campbell Scientific CR10X datalogger (Campbell Scientific, Shepshed, UK), and temperature was monitored by a Campbell Scientific 107 thermistor probe. The logging interval ranged from $20 \mathrm{~s}$ to $2 \mathrm{~h}$, depending on the experiment conducted.

\subsection{Relative humidity measurements}

Relative humidity (RH) was monitored by a polyimide coated fiber optic probe (Yeo et al., 2008) with UV-induced periodical refractive index modulation of the fiber core, in the form of a fiber Bragg grating (FBG). FBGs reflect light with a near Gaussian profile centered on a characteristic wavelength, which is also a function of temperature and strain (Meltz et al., 1989; Hill and Meltz, 1997). The polymer coating is sensitive to humidity, in that it absorbs moisture and swells in response (Yeo et al., 2008). The swelling causes a strain in the FBG, thus causing a change in the reflected Bragg wavelength (Venugopalan et al., 2008). A similar probe without coating that was sensitive to temperature only was also manufactured to compensate for the temperature effect of the humidity probe. The humidity and temperature probes were monitored with a Micron Optics Swept Laser Interrogator (SM125, Micron Optics, Atlanta, GA, USA) to monitor the Bragg wavelength. The probes were calibrated at $3^{\circ} \mathrm{C}, 7^{\circ} \mathrm{C}$, and $21^{\circ} \mathrm{C}$ by using saturated salt solutions to generate $\mathrm{RH}$ of $33 \%\left(\mathrm{MgCl}_{2}\right), 75 \%(\mathrm{NaOH})$, and $98 \%\left(\mathrm{H}_{2} \mathrm{O}\right.$ saturated sponge). The calibration was checked with a digital hygrometer (RS components) as an additional measure of RH.

The steel syringe tip of the Microx probe allowed it to be fixed into the rock without damaging the optical fiber. The FBG sensors were also protected with a stainless steel sheath, although the fiber was exposed for $0.5 \mathrm{~cm}$ at the tip. A $2 \mathrm{~mm}$ diameter hole was drilled into the surface of the rock to a depth of $3 \mathrm{~cm}$. The probes were inserted into the hole and cemented in place with a polymer sealant (Geocel Fixermate, RS Components) plug (Fig. 1D). Gas diffusion rates through several brands of sealant were tested for gas tightness; the selected type allowed minimal oxygen diffusion $(<1 \%$ air saturation) through a $0.5 \mathrm{~cm}$ plug over $60 \mathrm{~h}$. The Microx temperature probe was affixed to the exterior of the rock for the temperature and humidity experiments, and then a separate hole was drilled for insertion of the probe into the rock for the long-term oxygen experiment. The two holes drilled for implanting the probes have some effect on the overall porosity of the rock. However, the relatively small size of the holes $(<0.01 \%$ of the total volume of the rock sample) and the type of sealant plug on top allowed for minimal impact on our estimates of gas permeability.

\subsection{Laboratory tests}

2.7.1. Temperature. The instrumented rock was exposed to a range of different temperatures at the University of Bristol's LOWTEX facility. Temperature was monitored by both interior (at $3 \mathrm{~cm}$ depth) and exterior (affixed to the surface of the rock) probes (Fig. 1E). The temperature was cycled between $0^{\circ} \mathrm{C}, 7^{\circ} \mathrm{C}$, and $18^{\circ} \mathrm{C}$ over the course of $160 \mathrm{~h}$. Each cycle was repeated five times. Freeze-thaw conditions were also simulated by rapidly cycling the temperature between $-1.5^{\circ} \mathrm{C}$ and $+1.5^{\circ} \mathrm{C}$ over $20 \mathrm{~h}$ and between $-3^{\circ} \mathrm{C}$ and $+2^{\circ} \mathrm{C}$ for a further $10 \mathrm{~h}$.

2.7.2. Liquid water. The duration of wetting in the rock interior following a rainstorm was tested by mimicking a rainfall event. Approximately $6.5 \mathrm{~L}$ liquid water was poured onto the rock via a watering can rose for a duration of $1 \mathrm{~min}$. The $\mathrm{RH}$ at $3 \mathrm{~cm}$ depth in the rock was monitored for $48 \mathrm{~h}$ following the wetting, until the $\mathrm{RH}$ returned to room conditions (approximately 85\%). The retention of water was also tested by measuring the mass of basaltic rock samples after water saturation. Two small pieces of rock from the same outcrop were placed into water in a low-pressure vessel, and air was removed by vacuum. After the rocks were saturated, they were placed in the laboratory at a $\mathrm{RH}$ of $\sim 60 \%$, and their mass was measured every $4 \mathrm{~h}$.

2.7.3. Water availability and moisture adsorption properties. Water activity $\left(a_{\mathrm{w}}\right)$ describes water availability for microbial activity, as a ratio between the vapor pressure of water in a substrate $(p)$ and that of pure water $\left(p_{0}\right)(\mathrm{Eq} .3)$. The activity of pure water is 1.00 ; a substrate containing no free water has a smaller vapor pressure than pure water, and its $a_{\mathrm{w}}$ is consequently less (Magan, 2007). The water activity determines how tightly water is structurally or chemically bound with a substance and, hence, how available it is to microorganisms. An alternative measure is water potential $(\Psi,-\mathrm{MPa})$ (Eq. 4), where $R$ is the ideal gas constant, $T$ is absolute temperature, $P$ is atmospheric pressure, and $V$ is the volume of $1 \mathrm{~mol}$ of liquid water. The advantage of $\Psi$ is that it is possible to partition osmotic and matric components and their influence on growth and physiological functioning of microbes. In cells, the $V$ of the environment almost always equals that of the cell; thus, in most cases, the $\Psi$ is a function of the osmotic component. Determination of water availability in the rock sample can thus determine the ease with which microbes can extract liquid water bound in the rock matrix.

$$
\begin{gathered}
a_{\mathrm{w}}=\frac{p}{p_{0}} \\
\varphi=\frac{R T}{V} \log _{n} a_{\mathrm{w}}(+P)
\end{gathered}
$$

Milled basalt rock subsamples $(2 \mathrm{~g})$ were placed in glass Universal bottles. The range of $0.1-1.5 \mathrm{~mL}$ of water was added to replicates of these subsamples and allowed to equilibrate overnight at $4^{\circ} \mathrm{C}$ with occasional mixing. They were then allowed to equilibrate at ambient temperature (approximately $20^{\circ} \mathrm{C}$ ) in the laboratory. This enabled measurement of 
the pore pressure of the powder at a specified water volume. After final mixing, the samples were placed into sample holders for measuring the water activity/water potential at $25^{\circ} \mathrm{C}$ with an Aqualab CX-2 device (Decagon Devices, Pullman, WA, USA). The experiments were carried out twice. After measurement of the water activity/water potential, the samples were oven dried overnight at $80^{\circ} \mathrm{C}$ and the moisture content (percent wet weight basis) determined.

2.7.4. Oxygen. Low oxygen environments were simulated under wet and dry conditions via a gas bag (ColePalmer, IL, USA) filled with $\mathrm{N}_{2}$ gas and a water bath saturated with $\mathrm{N}_{2}$. Oxygen was monitored by the internal oxygen and temperature probe, and an additional oxygen probe was fixed to the rock exterior in order to compare rates of diffusion at the surface and into the rock interior. For the dry diffusion experiment, the instrumented rock was sealed inside the gas bag and the optical fibers allowed to exit via a gas outlet (Fig. 1E). The bag was filled with $\mathrm{N}_{2}$ gas until the internal oxygen probe recorded $<15 \%$ oxygen saturation. The rock was then removed from the bag and allowed to reequilibrate with the atmosphere. The cycle was repeated eight times at room temperature.

The rate of oxygen diffusion through water-saturated pore space was assessed by placing the instrumented sample in a deionized water bath at room temperature. $\mathrm{N}_{2}$ gas was bubbled into the bath until the internal oxygen probe recorded $<15 \%$ oxygen saturation, and then the bath was allowed to re-equilibrate with the atmosphere. A magnetic stirring bar was in operation throughout to provide constant rate of flow in the water bath.

2.7.5. Respiratory stimulation. The resident microbial community within the rock (Cockell et al., 2009b) was stimulated by the addition of yeast extract to provide a substrate for heterotrophic activity. Approximately $100 \mathrm{~mL}$ of yeast extract solution $\left(1 \mathrm{~g} \mathrm{~L}^{-1}\right)$, previously sterilized via autoclave, was injected into the rock via a syringe tip that was cemented into the rock surface, with the same polymer sealant (Geocel Fixermate, RS Components), and situated such that it was adjacent to the oxygen and temperature probes (Fig. 1F). The solution was added gradually over the course of $5 \mathrm{~h}$, and the oxygen saturation at $3 \mathrm{~cm}$ depth was monitored throughout. The exterior surface of the rock was previously sealed with polymer sealant to limit gas exchange with the atmosphere, and standard room temperature $\left(\mathrm{ca} .20^{\circ} \mathrm{C}\right)$ was maintained throughout the experiment.

\subsection{Heat transfer modeling}

To estimate the time taken for external changes in temperature to affect the rock interior, simple heat transfer modeling was undertaken. The rock sample and the field outcrop were represented as spheres, initially in equilibrium with the external air temperature. The thermal diffusivity was assumed to be equivalent to that of peralkaline phonolite: $8 \times 10^{-7} \mathrm{~m}^{2} \mathrm{~s}^{-1}$ (Gottsman and Dingwell, 2001), a similarly fine-grained volcanic glass. The heat transfer through the surface of the rock was equated to the transient heat gain by the volume of the rock, which in a sphere may be represented by Eq. 5, where $v$ is the volume of rock heated, $\alpha$ is the thermal diffusivity, $r_{1}$ and $r_{2}$ are the inner and outer radii, respectively, and $T_{1}$ and $T_{2}$ are the inner and outer temperatures.

$$
\frac{v}{\alpha} \frac{d T}{d t}=\frac{4 \pi r_{1} r_{2}\left(T_{1}-T_{2}\right)}{r_{2}-r_{1}}
$$

Assuming a known initial temperature, solving Eq. 5 yields Eq. 6, where $T_{\mathrm{s}}$ is the initial temperature of the rock, $T_{\mathrm{o}}$ is the outside temperature, and $T_{\text {int }}$ the temperature at the specified depth in the interior of the rock.

$$
T_{\text {int }}-T_{\mathrm{o}}=\left(T_{\mathrm{s}}-T_{\mathrm{o}}\right) e-\frac{4 \pi r_{1} r_{2} \alpha}{v\left(r_{2}-r_{1}\right)} t
$$

The temperature at a given time $t$ and depth into the rock can thus be evaluated. The value of $v$ determines the proportion of the rock which is heated and therefore how rapid the equilibration with external conditions. We assume that only a localized region of the rock is heated, since some of the outcrop is likely to be buried and thus insulated against external changes to some degree. Our estimates of the time taken for the interior temperature to change are therefore more conservative than if entire volume of the (spherical) rock was heated uniformly.

\section{Results}

\subsection{Porosity}

The internal pore area of the sample was $20.9 \mathrm{~m}^{2} \mathrm{~g}^{-1}$; Figure $1 \mathrm{~A}$ shows an image of the pore spaces. The total porosity of the rocks at the field site was $25.8 \%$. Figure 2 shows the relative abundance of different pore sizes within the rock sample. For the size range $0.02-200 \mu \mathrm{m}$, the pore volume for pores greater than $1 \mu \mathrm{m}$ (assumed here to be the typical size of a bacterium) was $14.2 \%$

\subsection{Temperature}

The response to external changes in temperature in the laboratory tests is shown in Fig. 3. There is a lag between the change in temperature at the surface of the rock and

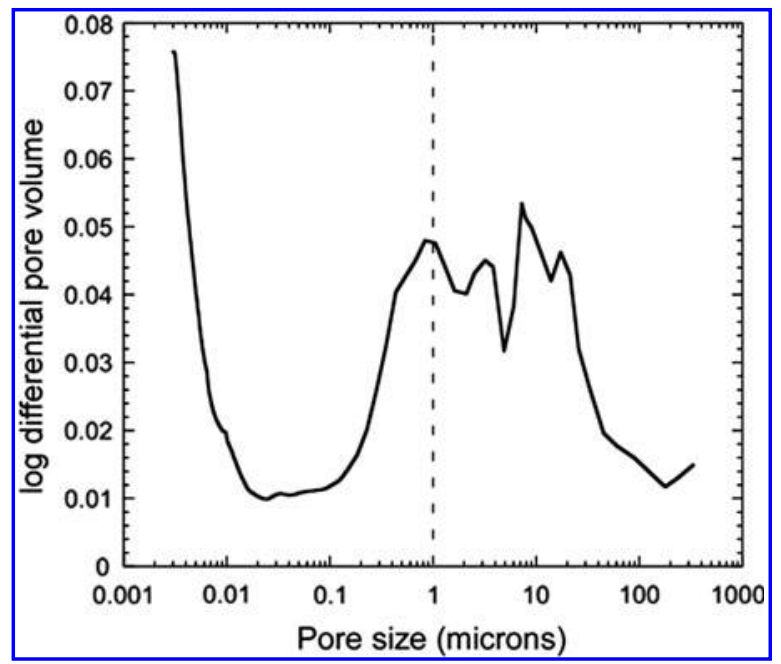

FIG. 2. Pore size distribution of the rock sample. The dotted line indicates the typical size of a bacterium, showing that the majority of pore spaces can accommodate microorganisms. 

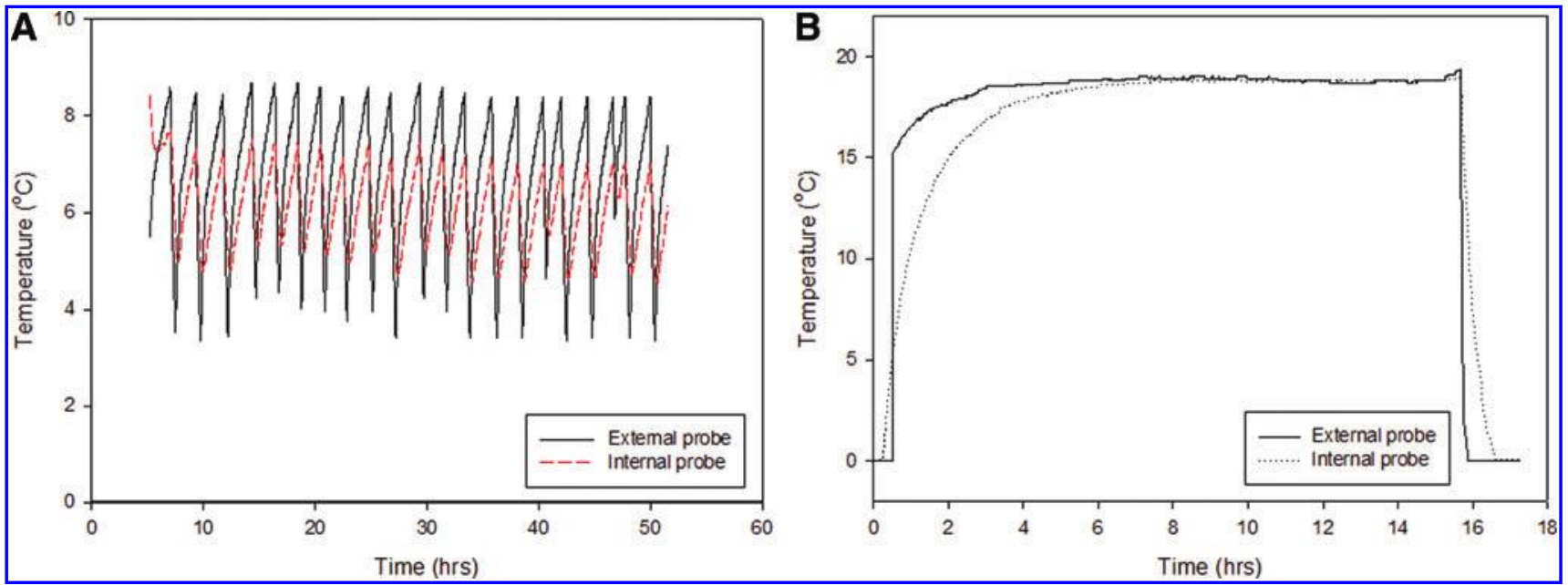

FIG. 3. Temperature measurements at the surface and interior $(3 \mathrm{~cm}$ depth) of the rock, under varying atmospheric conditions. The interior of the rock is buffered against rapid changes in temperature (A), but does reach near equilibrium with the surface after a varying time lag (B). Color graphics available online at www.liebertonline.com/ast

the change at $3 \mathrm{~cm}$ depth in the rock (Fig. 3A), which varied from 17 to $326 \mathrm{~min}$. The lag was shorter with decreasing temperatures $\left(18-0^{\circ} \mathrm{C}, 18-7^{\circ} \mathrm{C}\right.$, and $\left.7-0^{\circ} \mathrm{C}\right)$, with a mean of $30 \pm 15 \mathrm{~min}$. For increasing temperatures $\left(0-7^{\circ} \mathrm{C}, 7-18^{\circ} \mathrm{C}\right.$, and $\left.0-18^{\circ} \mathrm{C}\right)$, the mean lag was $130 \pm 120 \mathrm{~min}$. The few centimeters of rock buffered the internal probes from temperature fluctuations at the surface, with temperatures in the interior consistently remaining $0.5-2^{\circ} \mathrm{C}$ higher or lower than atmospheric conditions (Fig. 3A). Under freeze-thaw conditions, the internal probe recorded smaller-magnitude fluctuations in temperature than the external probe (Fig. 4). The interior ( $3 \mathrm{~cm}$ depth) remained above freezing, while the surface of the rock fell to $-1^{\circ} \mathrm{C}$. When temperatures were below $0^{\circ} \mathrm{C}$ for time periods of more than an hour, the interior probe did record negative temperatures but still remained at least $1^{\circ} \mathrm{C}$ warmer than the surface. Thermal conduction by the metal temperature probes implanted into the rock will have some effect on the internal measured temperature. However, we anticipated that this effect would be minimal in comparison with the overall heat transfer from the host rock. The thermocouples used to measure temperature in the field recorded similar temperature effects but were made of material with lower thermal conductance. Figure 5 shows the temperature measured at different depths in volcanic glass on typical summer and winter days (Fig. 5A) and over a whole year (Fig. 5C). The temperature probe at $20 \mathrm{~cm}$ depth recorded the least variation, particularly in the winter. By contrast, the shallowest probe, at $2 \mathrm{~cm}$ depth, and the surface probe recorded extreme and rapid variations in temperature, with $2 \mathrm{~cm}$ depth temperatures up to $19.3^{\circ} \mathrm{C}$ warmer than the ambient air temperature. Figure 5C shows the temperature recorded at $10 \mathrm{~cm}$ below the surface of a volcanic glass outcrop at the field site. The temperature is above zero for $5122 \mathrm{~h}$ of the monitored year; approximately $58 \%$.

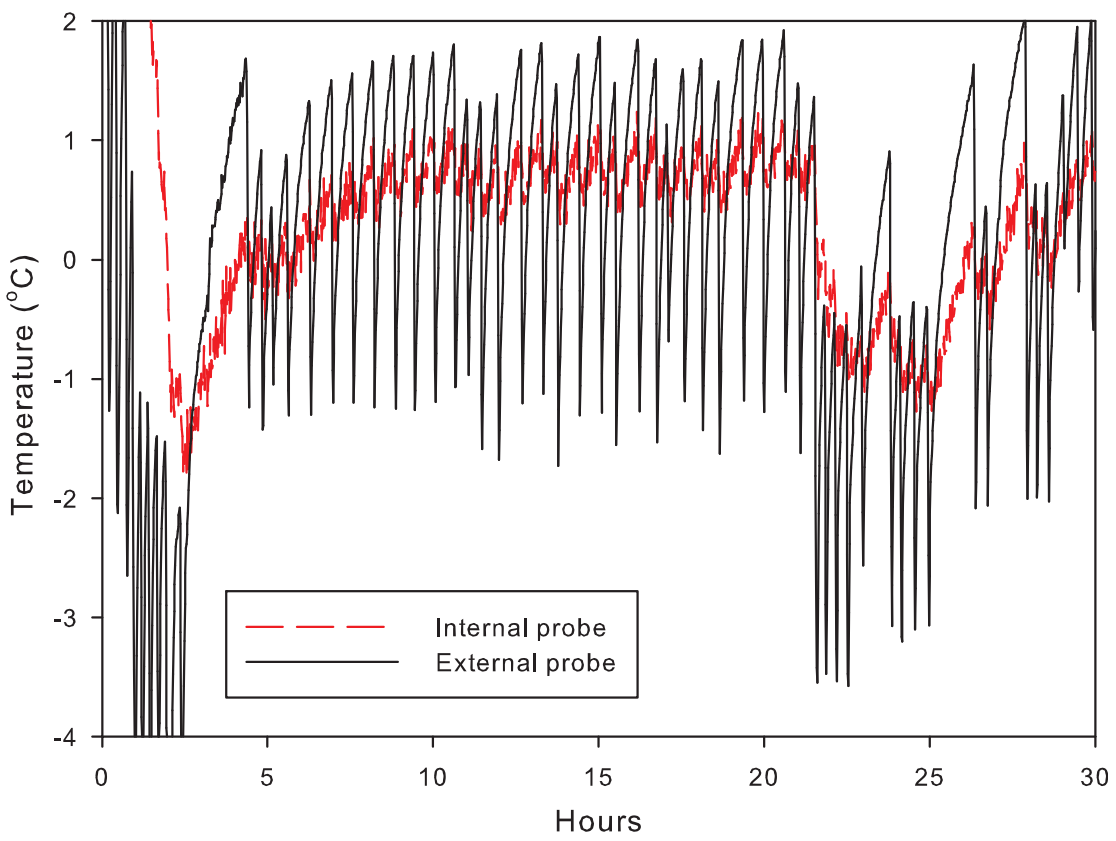

FIG. 4. Temperature monitored at the rock surface and at $3 \mathrm{~cm}$ depth during freeze-thaw cycling. The internal probe records fluctuations in temperature of lower magnitude than the exterior probe, indicating that the rock interior is protected from rapid freeze-thaw cycles. Color graphics available online at www .liebertonline.com/ast 


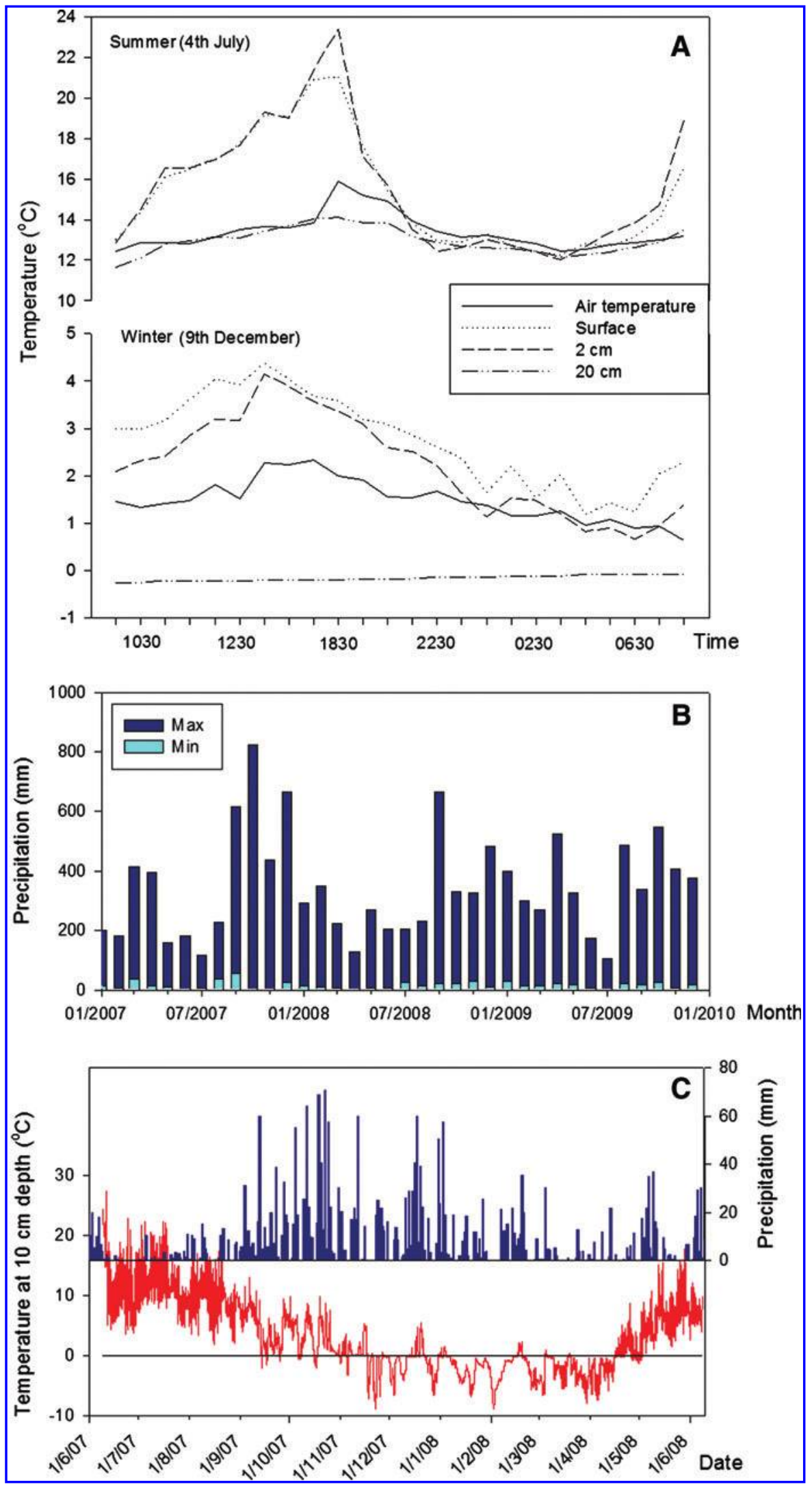

FIG. 5. Temperature and precipitation recorded at the field site (A, C), at Snæbýli (precipitation in C), and the maximum and minimum precipitation recorded at all meteorological stations in Iceland between 2007 and 2010 (B). Temperatures below different thickness of basalt are shown on a typical summer and winter day (A) and throughout the year (C). Color graphics available online at www.liebertonline.com/ast 

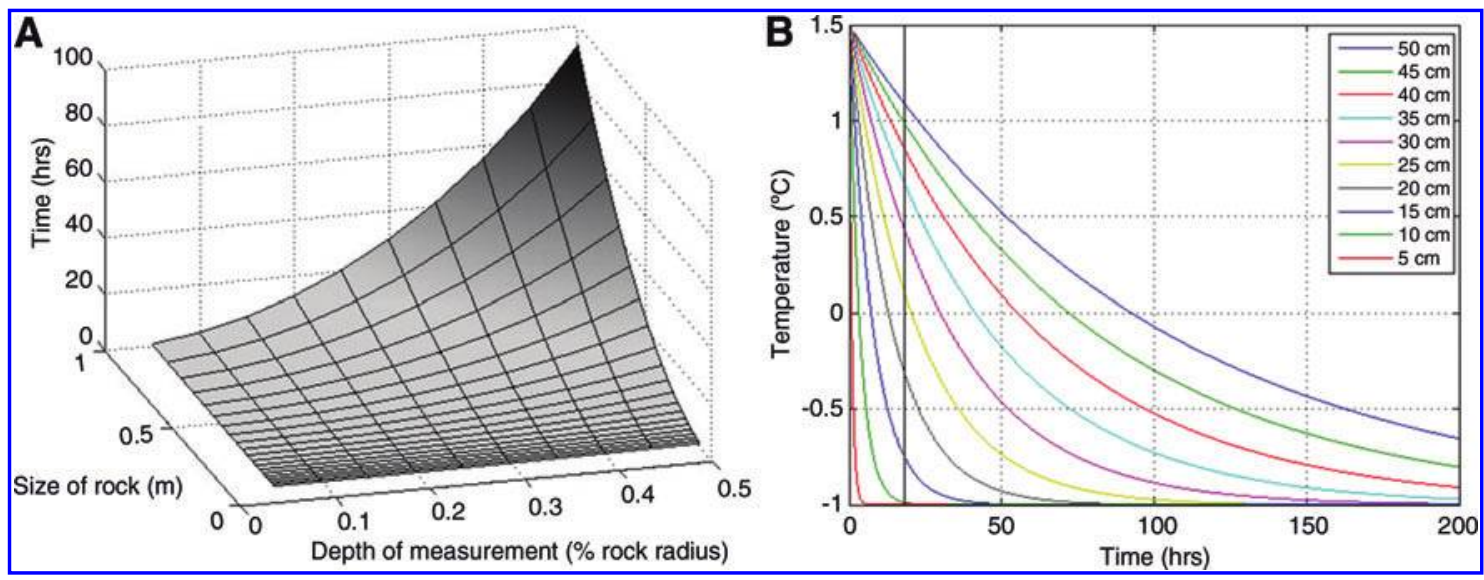

FIG. 6. Modeled heat flux into the interior of the rock, following an ambient temperature change from $1.5^{\circ} \mathrm{C}$ to $-1^{\circ} \mathrm{C}$. The size of the rock influences the speed of interior response (A), and the depth into an outcrop of constant size controls how rapidly the interior equilibrates (B). To remain above freezing for an $18 \mathrm{~h}$ Icelandic winter night, when external temperatures are subzero, the microbial community must be located at least $20 \mathrm{~cm}$ below the surface (B). Color graphics available online at www.liebertonline.com/ast

Figure 6A shows that, as the modeled exterior temperature was set below $0^{\circ} \mathrm{C}$, the time taken for the modeled interior temperature increased as the size of the rock sample increased. The size of the rock sample, as well as the depth into the sample, thus affects how long the interior temperatures are insulated from exterior changes. Our field and laboratory data agree with the modeled results; the interior temperature in the small rock sample fell below zero within an hour if external temperatures remained low, but the deepest probe in the rock outcrop $(20 \mathrm{~cm})$ remained at a relatively constant temperature throughout a day-night cycle in the winter (Fig. 5A). Figure 6B shows the temperature profile in the modeled rock outcrop (of constant size). As the depth into the outcrop increases, the time taken for the interior temperature to drop below zero increases. Assuming that the coldest temperatures occur during the night, a microbial community must be situated at least $20-25 \mathrm{~cm}$ below the rock surface for temperatures to remain above freezing during the course of an $18 \mathrm{~h}$ subzero Icelandic winter night. This concurs with the behavior of the field probes, where the probe at $20 \mathrm{~cm}$ depth recorded little fluctuation in temperature over a $24 \mathrm{~h}$ cycle (Fig. 5A).

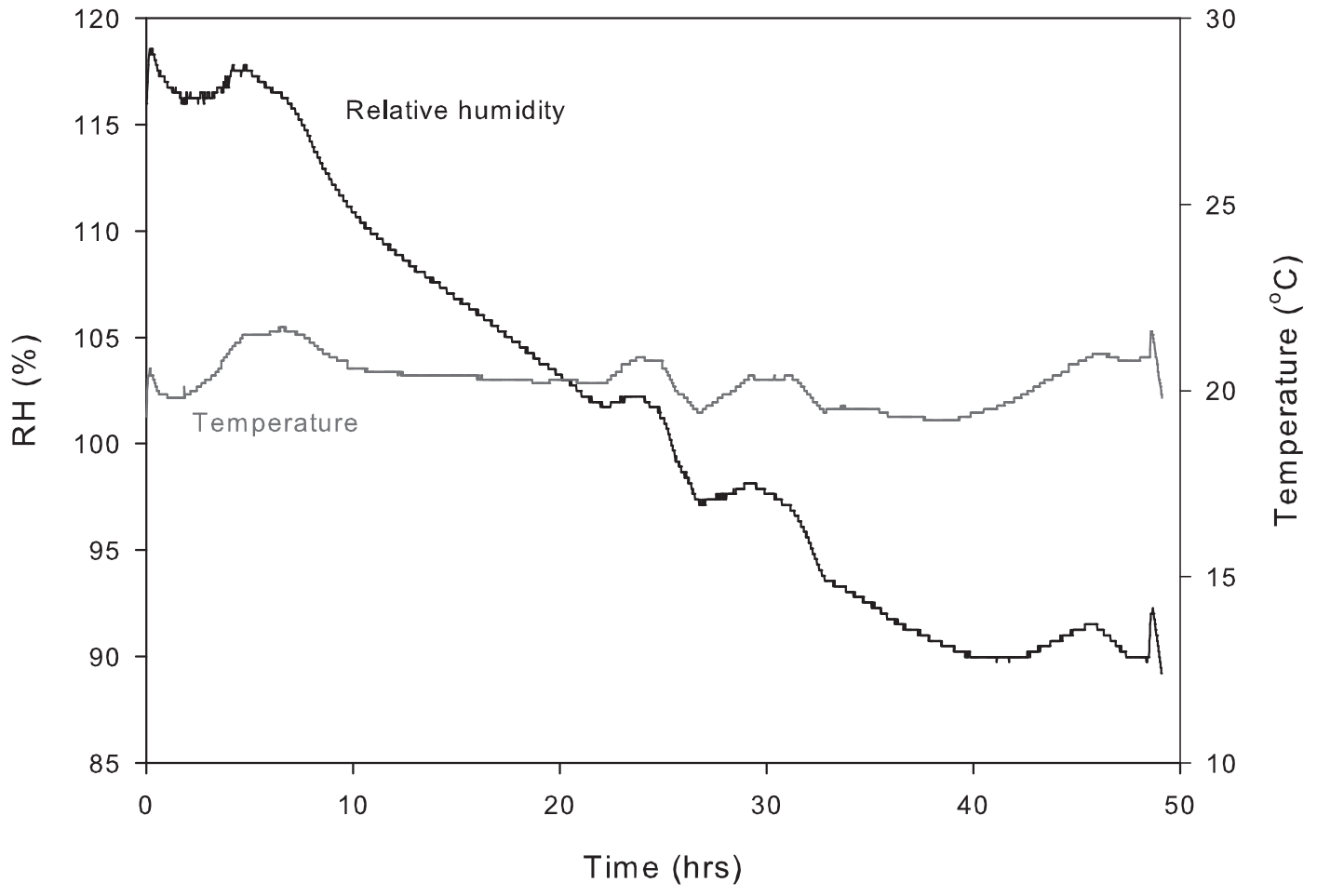

FIG. 7. Drying curve of the rock interior following a rainfall simulation. The interior $\mathrm{RH}$ probe detects moisture for $40 \mathrm{~h}$ after the event, when it reaches near equilibrium with atmospheric conditions (85\%). 


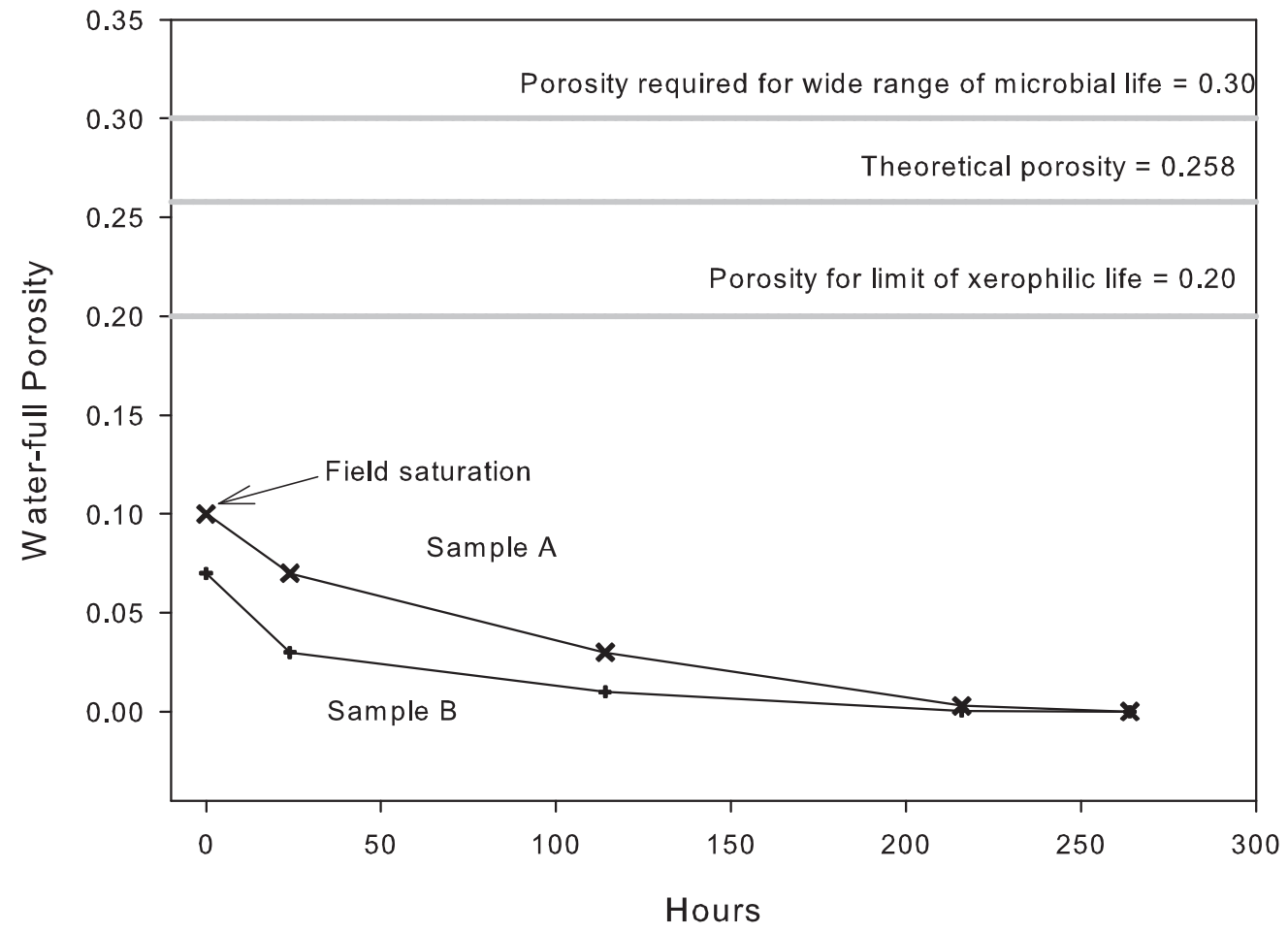

FIG. 8. Effective porosity for drying curve for visibly saturated rock samples A and B, and the measured porosity of the rock sample. The effective porosities required for the sample to maintain sufficient water activities for xerophiles and a wider range of microbial life (see Fig. 9 for water activities) are also illustrated.

\subsection{Water and water activity}

The rock interior remained moist for $40 \mathrm{~h}$ after wetting (Fig. 7). After this time, the interior and exterior probes were near equilibrium with atmospheric conditions $(87 \%$ in the laboratory). Laboratory temperature was higher than that at which the probes were calibrated $\left(26^{\circ} \mathrm{C}\right.$ versus $\left.21^{\circ} \mathrm{C}\right)$; thus, the recorded humidity exceeded $100 \%$. The absolute value of humidity does not affect this experiment, however, since we use the probe to detect the length of time that the rock interior

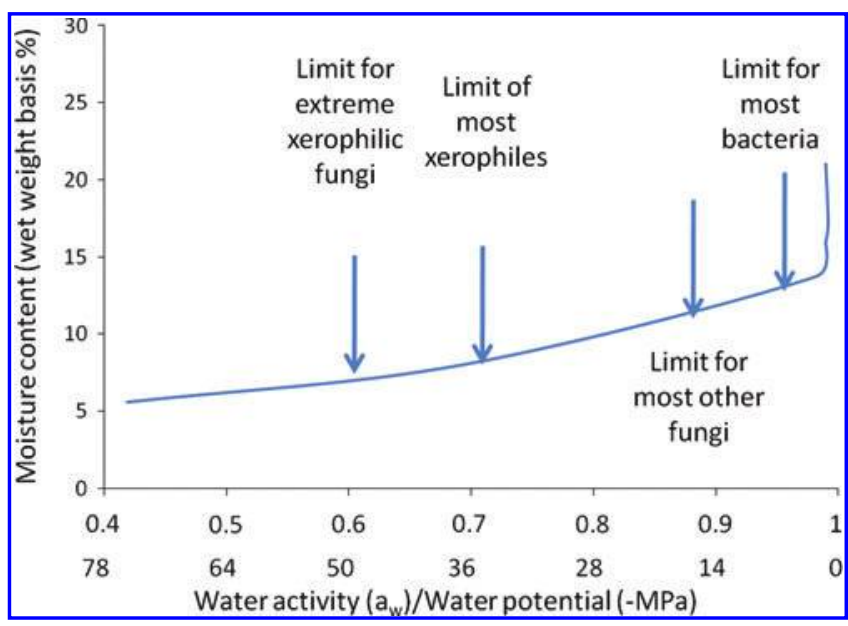

FIG. 9. Moisture adsorption for basalt glass/palagonite, showing the moisture content and associated water activity/ water potential required for activity of various microorganisms. Color graphics available online at www.liebertonline.com/ast remains wet. The rock surface remained a dark color (observed when the rock was wetted) for at least $48 \mathrm{~h}$, which indicates that water remained in some pore spaces. However, since the $\mathrm{RH}$ of the laboratory was high, we could not assess the extent of wetness except in comparison with atmospheric conditions.

Figure 8 shows a drying curve for two rock samples from the field site (sample A, mass 25.73g; sample B, mass $13.16 \mathrm{~g})$, which contained $4.1 \%$ and $5.3 \%$ of their mass in water at visible surface saturation. After $24 \mathrm{~h}$, these values had dropped to $2.9 \%$ and $2.6 \%$, respectively. After $144 \mathrm{~h}$, they had dropped to $1.36 \%$ and $0.67 \%$, and after $216 \mathrm{~h}$ they had dropped to $0.14 \%$ and $0.03 \%$, respectively. After $264 \mathrm{~h}$, there was no measurable water content. The porosity associated with the percent wet weight at visible surface saturation is well below the value measured by BET analysis and mercury intrusion porosimetry, possibly because measurements were taken before sufficient liquid water had diffused into the interior of the rock to cause saturation (Fig. 8).

Figure 5C shows the precipitation measured at Snæbýli, $60.3 \mathrm{~km}$ from the collection site, during the monitoring period. In this year, there were 241 days when precipitation was recorded. This compares to a mean of 222 days per year for 2007-2010; approximately $61 \%$ of the year. Figure 5B shows the maximum and minimum precipitation measured at all of the Icelandic Meteorological Office monitoring stations between January 2007 and 2010. Mean daily precipitation can range from 0 to $800 \mathrm{~mm}$ in a single month.

Figure 9 compares the water activity with water saturation for the milled rock. Water retention properties of the rock material are such that very little water is retained. Only under very wet conditions is some of the water retained within intergranular spaces, which suggests that the structure of the 

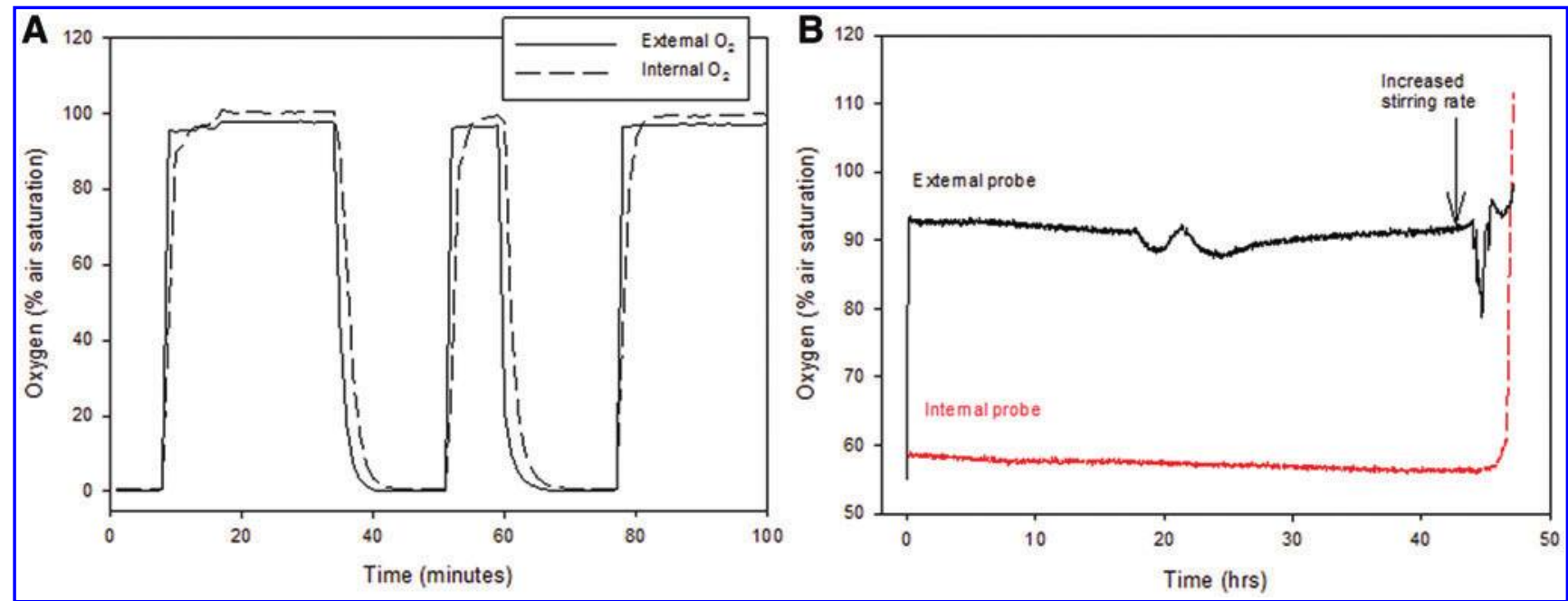

FIG. 10. Oxygen saturation at the surface and within the rock under varying oxic conditions in air (A) and water (B). The interior probe records rapid equilibration with surface conditions in air after a short time lag, but in water the interior remained at low oxygen until the water flow rate in the bath increased. Color graphics available online at www.liebertonline.com/ast

porous rock matrix has more influence on water-holding capacity than the rock material itself. The shape of the curve is unusual when compared to a sandy loam or agricultural soil (Magan, 2007) because of the lack of organic matter to bind water.

\subsection{Oxygen}

Figure 10A shows the lag between changes in oxic conditions at the surface and in the rock interior under dry conditions. The lag between exterior and interior changes ranged from 1 to $8 \mathrm{~min}$, with a mean of $2 \mathrm{~min}$, for both increasing and decreasing oxygen concentrations. This shows potentially rapid equilibration between the interior of the rock and its surroundings. Assuming that diffusion coefficient (distance/time) is $0.00025 \mathrm{~m}^{2} \mathrm{~s}^{-1}$, the oxygen diffusion coefficient is $0.00197 \mathrm{~m}^{2} \mathrm{~s}^{-1}$ (Bird et al., 1960), and the porosity is 0.258 , then the tortuosity is calculated to be 2.03 . This compares favorably with estimates of tortuosity in other volcanic glasses that range from 1.47 (perlite) to 1.63 (vermiculite) (Voronina and Horoshenkov, 2004), which shows that the rock is certainly permeable. When the experiment was repeated in water, the rate of equilibration depended on the rate of stirring in the water bath (achieved by using a magnetic stirrer) and, hence, the rate of flow in and out of the pore spaces. Equilibrium was attained more rapidly with a faster flow rate (Fig. 10B). When flow rates were low, equilibrium was either not attained or reached after several days.

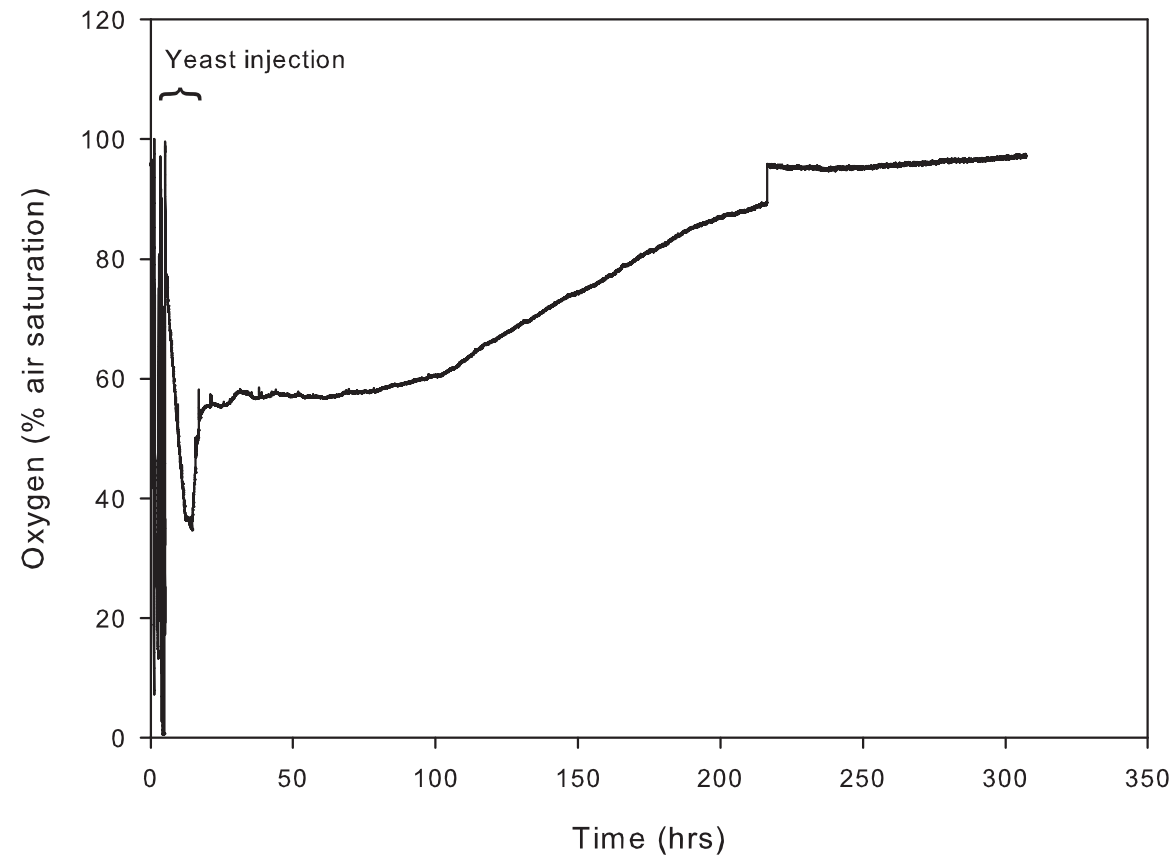

FIG. 11. Oxygen saturation within the rock following an injection of yeast solution $\left(1 \mathrm{~g} \mathrm{~L}^{-1}\right)$. Low oxygen conditions develop quickly and are maintained for some $60 \mathrm{~h}$. 


\subsection{Heterotrophic activity}

Low oxygen conditions developed rapidly in the interior of the rock following the addition of a bioavailable substrate (yeast solution) (Fig. 11). After the substrate was introduced, oxygen saturation steadily decreased from $100 \%$ to $35 \%$ over the course of $8 \mathrm{~h}$ [where $100 \%$ indicates that the gas or liquid (air or water) is fully saturated with respect to oxygen]. The lowest values of oxygen saturation were maintained for $3 \mathrm{~h}$, before increasing to a plateau of $57 \%$. The rock interior remained at $57 \%$ air saturation for $60 \mathrm{~h}$ and then slowly returned to equilibrium with the external atmosphere over the next $150 \mathrm{~h}$.

\section{Discussion}

Weathered glasses are an abundant substrate for microbial growth in volcanic terrains, particularly in volcanically active plate margins and in the vicinity of hot-spot volcanoes. Despite their importance in many Earth-system processes and their potential in the search for life elsewhere, the physical conditions for microorganisms within these substrates are not well known.

The interior of the Sedgwick hyaloclastite sampled here is characterized by a network of interconnected pore spaces. These pore spaces provide a microhabitat for microorganisms to colonize, particularly since the majority of pore sizes can accommodate a typical-sized bacterium (Fig. 2). The pore spaces thus provide a network of channels for a diversity of organisms, potentially including filamentous actinobacteria, which have been cultured in samples from the same outcrop (Cockell et al., 2009b). Endolithic communities are sheltered from extreme atmospheric conditions that affect the exterior of rocks, particularly in cold climates and in volcanic regions. However, the degree of connectivity between the atmosphere and the interior pore spaces that house the microorganisms is generally unknown.

These data show that the rock interior is buffered against very rapid changes in temperature, particularly with respect to freeze-thaw (Figs. 3A, 4, and 5), but that in exposed outcrops, near equilibrium with the atmosphere is reached within an hour at $3 \mathrm{~cm}$ depth. In short-term laboratory freeze-thaw tests, the rock interior did not reach equilibrium but remained either warmer or cooler than the exterior, whichever was closest to ambient atmospheric conditions. This suggests that endolithic communities are to some degree protected against fluctuations in air temperature, as well as extreme hot or cold, as has been hypothesized in the McMurdo Dry Valleys of Antarctica where rock interiors may be $10^{\circ} \mathrm{C}$ warmer than the ambient air temperature (McKay and Friedmann, 1985; de la Torre et al., 2003). McKay and Friedmann (1985) showed that in the field the interior of cryptoendolithically colonized sandstones was frequently above freezing while air temperature was below. Field observations and heat transfer modeling showed that deeper pores are most insulated from fluctuations in air temperature (Figs. 5 and 6). Those at $20 \mathrm{~cm}$ depth can remain at relatively constant, mean annual temperatures, despite fluctuations of several degrees in air temperature and up to $30^{\circ} \mathrm{C}$ on the rock surface, as a consequence of solar heating. The rock does not remain at a constant low temperature for a sufficient period of time to alter the temperature of the deepest probe on many winter days due to day-night cycles, seasonality, and weather. The moderate thermal inertia of the rock material thus provides protection against rapid freeze-thaw cycles. The degree of protection provided by the rock material against these fluctuations ultimately depends on the temperature amplitude, the depth, and the time cycle (for example, $\sim 24 \mathrm{~h}$ on Earth and Mars). The thermal inertia is raised by weathering, which creates additional porosity and hence provides buffering against rapid changes to the rock interior. This is particularly relevant when considering the retention time of liquid water within the pore spaces. Figure 7 shows that liquid water may be retained within the rock for at least $40 \mathrm{~h}$ following a wetting event. If water retention is coupled with protection from freezing, then the presence of liquid water and, hence, clement conditions for biological activity can be maximized following a precipitation event. A balance between sufficient porosity to retain water and an adequate volume of bulk, unweathered material that has sufficient thermal inertia to provide protection from temperature fluctuations must be found in order to maintain habitable pore spaces for prolonged time periods.

The water-holding capacity of the pore spaces contrasts with the holding capacity of the material itself. The water activity/water potential studies show that the material has poor liquid water-holding capacity (Fig. 8). These observations are partly accounted for by the lack of organic carbon, which contributes to water holding in other substrates such as soils (Magan, 2007), and the nature of the product of weathered basaltic glass, palagonite. Our data show that, when the crushed material is in equilibrium with the atmosphere, the water activity/water potential of the surface of the glass/palagonite in the rock is below the lower limits for any microbial growth. However, when the material is wetted, and thus there is free water in the pore spaces, it can potentially support a more diverse range of organisms. Xerophiles would be able to survive and perhaps actively grow at $\sim 8 \%$ wet weight (Magan, 2007). At higher moisture contents of $12 \%$, equivalent to 0.90 water activity/-14 MPa water potential, the rock could support the growth of a wider range of microorganisms, while at $>0.95$ water activity/-7.0 MPa water potential ( $\sim 13 \%$ moisture content), both actinomycetes and a range of fungi would be supported. The effective water activity of the wetted rock is thus a more important parameter than the theoretical water activity of the rock material. The key to survival of microorganisms in this environment is therefore regular access to external sources of liquid water.

Unlike some salt materials that exhibit deliquescence (Davila et al., 2008), volcanic glass and palagonite do not have this characteristic, and the only time the surface of the material is raised to a sufficiently high water activity is when the material receives liquid water. The data also show that, when the rock dries, the material loses water rapidly, with water activity dropping linearly with loss of moisture content (Figs. 7, 8, and 9). Although the whole rock-wetting experiments showed that the rock samples contain less than $6 \%$ mass of water when saturated, it is difficult to estimate quantitatively the length of time it takes for rock internal moisture to drop below the critical values measured in the water activity experiments. Figure 8 shows that the measured surface saturation of rock samples A and B in the field is well below the theoretical water-full porosity of the material and below the required pore water pressure that could 
support sufficient water activity for even xerophilic life. Surface saturation is not a good indicator of water availability for microbial growth (Magan, 2007). The moisture content in any given location in the rock will depend on the distribution of water through the pore spaces, the mass of palagonite accessible to water, and the spatial heterogeneity of water loss from the rock, among other factors. Hence, the water available in the rock sample for microbial growth is determined by the structure of the rock sample, not the theoretical holding capacity of the milled rock material. The slow rock-atmosphere gas exchange observed in watersaturated rocks (Fig. 10B) suggests that water can become located in restricted spaces within the rock, and the retention of water at $>0.5 \%$ mass of the rock for 6 days suggests that in some locations water activity might remain above the limits for growth after wetting events, even if the rock as a whole is undersaturated.

The precipitation data shown in Fig. 5 suggest that the rock outcrop would typically be wet for 222 days, or $61 \%$ of the year. The amount of available liquid water will fluctuate, according to the magnitude and type of precipitation; for example, snowfall would provide little water initially but may saturate the rock on melting. A crude estimate of the amount of time that the rock interior receives adequate precipitation for wetting can be obtained by counting the number of days of the year when precipitation is recorded and when the interior rock temperature at $10 \mathrm{~cm}$ depth is above zero at midday. When both conditions are simultaneously met, this gives the percentage of the year when conditions at this depth in the rock are potentially favorable for microbial activity. Between June 9, 2008, and June 9, 2009, these conditions were met on 142 days of the year, which equates to $38.9 \%$ or approximately $3400 \mathrm{~h}$. Temperatures may have been above zero at other times of day and were hence not counted by this study. In addition, water from dewfall or rime has been shown to support endolithic biological activity (Buedel et al., 2008), and glacial melt may provide a further source of liquid water. The real habitability will depend on the speed of diffusion of liquid water into the interior of the rock and the potential for water to remain trapped in pores in sufficient quantities to maintain minimum levels of water activity. Nevertheless, we show the potential for basic physical conditions for biological activity to be met at $10 \mathrm{~cm}$ depth in the rock outcrop for a significant proportion of the year, particularly in the spring and autumn months.

These data suggest that there is frequently sufficient liquid water available in the interior of volcanic glass to enable biological activity and that the deeper pore spaces have fairly constant temperatures. However, the fluctuating availability of liquid water and the very low holding capacity of the rock material itself suggests that the microorganisms that inhabit the pore spaces must adapt to varying water availability and potentially "switch on" rapidly following a wetting event to maximize optimal physical conditions for biological activity. Similar behavior has been recorded in extreme habitats for life elsewhere, including the McMurdo Dry Valleys (McKnight et al., 1999; Buedel et al., 2008) and the Atacama Desert, Chile (Warren-Rhodes et al., 2006). There must be a compromise depth where the rock thickness is sufficient to protect from freeze-thaw events but at which liquid water can easily diffuse following a surface wetting event. Our laboratory experiment results (Figs. 3 and 4) suggest that even a few centimeters of rock material are sufficient to protect from short-term temperature fluctuations of around $1-2^{\circ} \mathrm{C}$ and that liquid water can be maintained for several hours after a wetting event at this depth (Fig. 7). Further monitoring of humidity conditions in pore spaces at a variety of depths in a field outcrop following a rain event is required to determine the likely depth limit of microbial life in volcanic glass, but we surmise that access to water is likely to be a key limitation on microbial growth in volcanic rocks.

The dense network of pore spaces allows relatively rapid gas exchange between the interior and the atmosphere (Fig. 10A). The degree of liquid water saturation will affect the speed of diffusion of oxygen into the interior pore spaces. Our data show that oxygen diffusion is slower when the pores are saturated (Fig. 9); thus, again a compromise must be reached between access to sufficient oxygen and liquid water to support microbial activity under oxic conditions. Our suite of laboratory tests have shown that under normal conditions, for example, when the microbial substrate is the rock itself, there is little opportunity for widespread anoxia to develop through natural rates of community respiration. However, when access to the atmosphere is restricted and a substrate is added, then low oxygen conditions develop and are maintained for long periods (Figs. 10B and 11). This scenario gives us some insight into situations that could arise in micro-environments within the pore space.

Since newly formed volcanic rocks contain limited quantities of organic material, naturally occurring substrate for heterotrophs in the rock interior is limited to allochthonous material delivered into the rock or autochthonous material exuded by other organisms, either living or dead (Cockell et al., 2009b). Allochthonous sources of carbon and nutrient include organic material in rainwater and snowmelt, and potentially the inwash of dead organisms or products of eolian deposition in the vicinity. The distribution of available substrate within the rock is therefore heterogeneous. Enhanced heterotrophic activity may occur in locations where the substrate is enriched by inwashed or overridden material. These could include locations with more restricted pore spaces, regions where a heterogeneous distribution of cells within the rock (Cockell et al., 2009b) concentrate biological activity in small zones within the pore space, and potentially spaces at the palagonite-glass interface. These locations may catalyze the rapid development of low oxygen or anoxic microenvironments, as modeled on the larger-scale zones of low oxygen that we observed in our sample (Fig. 11). In addition, volcanic glass frequently forms in subglacial locations when molten rock comes into contact with liquid water present at the bed of ice masses (Gow et al., 1968; Fountain and Walder, 1998; Jacobsson and Gudmundsson, 2008). The ice restricts access to the atmosphere and increases the likelihood of low oxygen zones within the outcrop. These results are dependent on the nature of the pore network present in our small sample. They also depend on the concentration of yeast extract injected, the extent of liquid water saturation of the pore spaces, and the distribution of microorganisms within the rock. However, the experiment does demonstrate the possibility of widespread low oxygen conditions in larger pore spaces (where the monitoring probes were located) as a result of heterotrophic activity and, hence, the potential for hypoxic and perhaps anoxic microenvironments to develop in isolated zones in the outcrop interior.

Culture and culture-independent methods show the presence of a diversity of taxa in Icelandic rocks with 
obligately or facultatively anaerobic members, including Firmicutes, Bacteroidetes, Actinobacteria, and Proteobacteria (Cockell et al., 2009b; Herrera et al., 2009; Kelly et al., 2010). Anaerobic and microaerophilic taxa from material at the rock-soil interface in Iceland have previously been isolated, including members of the genera Ralstonia, Bacillus, Burkholderia, Acidocella (Wilkinson, unpublished data). These data suggest that a diversity of organisms in basaltic glasses could make use of locally anaerobic or low oxygen conditions.

The function of the microbial community within the rock is thus influenced by both physical conditions and the availability of substrate. In zones where there is both liquid water and an available source of carbon and nutrient for production, low oxygen conditions may develop, which in turn might stimulate other members of the microbial assemblage. Our data are specific to this particular rock size and shape. The relatively small size of the rock sample limits the diversity of the community, the number of pores able to retain water, the availability of micropore spaces for low oxygen conditions to develop, and the thermal inertia of the material. However, the in situ temperature and rainfall data from the outcrop have shown that minimum physical conditions for biological activity can be maintained for at least $38.9 \%$ of the year. In a larger outcrop, there is an increased probability of biologically diverse, interconnected pore spaces than in our small sample. Therefore, we assume that our data is applicable to a small sample but that it is probable that a larger outcrop would be even more hospitable if a compromise can be met between adequate protection from freezing and access to sufficient liquid water.

\section{Conclusions}

In conclusion, we have characterized a novel extreme environment in the interior of weathered exposed basaltic glasses. With low water retention and rapid equilibration with the atmosphere, microorganisms are subjected to growth limitation caused by low water activities and extreme temperatures. Although rocks can retain water for tens of hours after wetting events, loss of water is generally rapid, and thus the rocks are also a desiccating environment. However, rock thermal inertia, similar to other rocks, can protect against freeze-thaw if there is sufficient thickness of rock material. The interior of weathered basaltic glass may also provide a location for metabolisms that cannot be sustained on rock surfaces. In particular, local microenvironments within rocks may allow for the transient activity of anaerobic microorganisms in an otherwise aerobic atmosphere.

\section{Acknowledgments}

This work was supported by EPSRC grant EP/D057620/1. Humidity testing was undertaken at the University of Southampton, where Prof. Janice Barton, Dr. Chen Ye, and Nick Heijne provided the swept laser interrogator. The Icelandic Meteorological Office provided temperature and precipitation data. The comments of Vincent Chevrier and two anonymous reviewers greatly improved the manuscript.

\section{Disclosure Statement}

No competing financial interests exist.

\section{Abbreviations}

BET, Brunauer-Emmett-Teller; FBG, fiber Bragg grating; $\mathrm{RH}$, relative humidity.

\section{References}

Adamo, P., Marchetiello, A., and Violante, P. (1993) The weathering of mafic rocks by lichens. Lichenologist 25:285-297.

Allen, C.C., Gooding, J.L., Jerinovic, M., and Keil, K. (1981) Altered basaltic glass-a terrestrial analog to the soil of Mars. Icarus 45:347-369.

Bell, R.A. (1993) Cryptoendolithic algae of hot semiarid lands and deserts. [Phycol 29:133-139.

Bird, R.B., Stewart, W.E., and Lightfoot, E.N. (1960) Transport Phenomena, John Wiley and Sons, New York.

Broady, P.A. (1982) Green and yellow-green terrestrial algae from Surtsey (Iceland) in 1978. Surtsey Research Progress Report 9:13-32.

Brock, T.D. (1973) Primary colonization of Surtsey, with special reference to the blue-green algae. Oikos 24:239-243.

Brunauer, S., Emmett, P.H., and Teller, E. (1938) Adsorption of gases in multimolecular layers. IAm Chem Soc 60:309-319.

Buedel, B., Bendix, J., Bicker, F.R., and Green, T.G.A. (2008) Dewfall as a water source frequently activates the endolithic cyanobacterial communities in the granites of Taylor Valley, Antarctica. L Phycol 44:1415-1424.

Cockell, C.S., Olsson-Francis, K., Herrera, A., and Meunier, A. (2009a) Alteration textures in terrestrial volcanic glass and the associated bacterial community. Geobiology 7:50-65.

Cockell, C.S., Olsson, K., Herrera, A., Kelly, L., Thorsteinsson, T., and Marteinsson, V. (2009b) Bacteria in weathered basaltic glass, Iceland. Geomicrobiol I 26:491-507.

Cockell, C.S., van Calsteren, P., Mosselmans, J.F.W., Franchi, I.A., Gilmour, I., Kelly, L., Olsson-Francis, K., Johnson, D., and Party, J.C.S.S. (2010) Microbial endolithic colonization and the geochemical environment in young seafloor basalts. Chem Geol 279:17-30.

Davila, A.F., Gomez-Silva, B., de los Rios, A., Ascaso, C., Olivares, H., McKay, C.P., and Wierzchos, J. (2008) Facilitation of endolithic microbial survival in the hyperarid core of the Atacama Desert by mineral deliquescence. J Geophys Res 113, doi:10.1029/2007JG000561.

de la Torre, J.R., Goebel, B.M., Friedmann, E.I., and Pace, N.R. (2003) Microbial diversity of cryptoendolithic communities from the McMurdo Dry Valleys, Antarctica. Appl Environ Microbiol 69:3858-3867.

Demas, J.N., DeGraff, B.A., and Coleman, P.B. (1999) Oxygen sensors based on luminescence quenching. Anal Chem 71: 793A-800A.

Dessert, C., Dupre, B., Gaillardet, J., Francois, L.M., and Allegre, C.J. (2003) Basalt weathering laws and the impact of basalt weathering on the global carbon cycle. Chem Geol 202: 257-273.

Draxler, S., Lippitsch, M.E., Klimant, I., Kraus, H., and Wolfbeis, O.S. (1995) Effects of polymer matrices on the time-resolved luminescence of a ruthenium complex quenched by oxygen. LPhys Chem 99:3162-3167.

Etienne, S. and Dupont, J. (2002) Fungal weathering of basaltic rocks in a cold oceanic environment (Iceland): comparison between experimental and field observations. Earth Surface Processes and Landforms 27:737-748.

Fisk, M.R., Giovannoni, S.J., and Thorseth, I.H. (1998) Alteration of oceanic volcanic glass: textural evidence of microbial activity. Science 281:978-980. 
Fountain, A.G. and Walder, J.S. (1998) Water flow through temperate glaciers. Rev Geophys 36:299-328.

Friedmann, E.I. (1980) Endolithic microbial life in hot and cold deserts. Orig Life Evol Biosph 10:223-235.

Gomez-Alvarez, V., King, G.M., and Nusslein, K. (2007) Comparative bacterial diversity in recent Hawaiian volcanic deposits of different ages. FEMS Microbiol Ecol 60:60-73.

Gottsman, J. and Dingwell, D.B. (2001) Cooling dynamics of spatter-fed obsidian flows on Tenerife, Canary Islands. Journal of Volcanology and Geothermal Research 105:323-342.

Gow, A.J., Ueda, H.T., and Garfield, D.E. (1968) Antarctic ice sheet-preliminary results of first core hole to bedrock. Science 161:1011-1013.

Hamilton, V.E., Morris, R.V., Gruener, J.E., and Mertzman, S.A. (2008) Visible, near-infrared, and middle infrared spectroscopy of altered basaltic tephras: spectral signatures of phyllosilicates, sulfates, and other aqueous alteration products with application to the mineralogy of the Columbia Hills of Gusev Crater, Mars. J Geophys Res 113, doi:10.1029/ 2007JE003049.

Head, J.W. and Marchant, D.R. (2003) Cold-based mountain glaciers on Mars: Western Arsia Mons. Geology 31:641-644.

Herrera, A., Cockell, C.S., Self, S., Blaxter, M., Reitner, J., Thorsteinsson, T., Arp, G., Dröse, W. and Tindle, A.G. (2009) A cryptoendolithic community in volcanic glass. Astrobiology 9:369-381.

Hill, K.O. and Meltz, G. (1997) Fiber Bragg grating technology fundamentals and overview. Journal of Lightwave Technology 15:1263-1276.

Jacobsson, S.P. and Gudmundsson, M.T. (2008) Subglacial and intraglacial volcanic formations in Iceland. Jokull 58:179-196.

Kelly, L., Cockell, C.S., Piceno, Y.M., Andersen, G.L., Thorsteinsson, T., and Marteinsson, V. (2010) Bacterial diversity of weathered terrestrial Icelandic volcanic glasses. Microb Ecol 60:740-752.

Klimant, I., Meyer, V., and Kuhl, M. (1995) Fiberoptic oxygen microsensors, a new tool in aquatic biology. Limnol Oceanogr 40:1159-1165.

Laan, E.C., Volten, H., Stam, D.M., Munoz, O., Hovenier, J.W., and Roush, T.L. (2009) Scattering matrices and expansion coefficients of martian analogue palagonite particles. Icarus 199:219-230.

Lysnes, K., Thorseth, I.H., Steinsbu, B.O., Ovreas, L., Torsvik, T., and Pedersen, R.B. (2004) Microbial community diversity in seafloor basalt from the Arctic spreading ridges. FEMS Microbiol Ecol 50:213-230.

Magan, N. (2007) Fungi in extreme environments. In Environmental and Microbial Relationships, The Mycota, Vol. 4, $2^{\text {nd }}$ ed., edited by C.P. Kubicek and I.S. Druzhinina, Springer Verlag, Berlin, pp 85-103.

Mason, O.U., Stingl, U., Wilhelm, L.J., Moeseneder, M.M., Di Meo-Savoie, C.A., Fisk, M.R., and Giovannoni, S.J. (2007) The phylogeny of endolithic microbes associated with marine basalts. Environ Microbiol 9:2539-2550.

McKay, C.P. and Friedmann, E.I. (1985) The cryptoendolithic microbial environment in the Antarctic cold desert-temperature variations in nature. Polar Biol 4:19-25.

McKnight, D.M., Niyogi, D.K., Alger, A.S., Bomblies, A., Conovitz, P.A., and Tate, C.M. (1999) Dry Valley streams in Antarctica: ecosystems waiting for water. Bioscience 49:985-995.
Meltz, G., Morey, W.W., and Glenn, W.H. (1989) Formation of Bragg gratings in optical fibers by a transverse holographic method. Opt Lett 14:823-825.

Michalski, J.R., Kraft, M.D., Sharp, T.G., and Christensen, P.R. (2005) Palagonite-like alteration products on the Earth and Mars I: Spectroscopy (0.4-25 microns) of weathered basalts and silicate alteration products [abstract 1188]. In $36^{\text {th }}$ Lunar and Planetary Science Conference Abstracts, Lunar and Planetary Institute, Houston.

PreSens (2006) Instruction Manual Fibox 3, Regensburg, Germany. Ruff, S.W., Christensen, P.R., Blaney, D.L., Farrand, W.H., Johnson, J.R., Michalski, J.R., Moersch, J.E., Wright, S.P., and Squyres, S.W. (2006) The rocks of Gusev Crater as viewed by the Mini-TES instrument. J Geophys Res 111, doi:10.1029/ 2006JE002747.

Santelli, C.M., Orcutt, B.N., Banning, E., Bach, W., Moyer, C.L., Sogin, M.L., Staudigel, H., and Edwards, K.J. (2008) Abundance and diversity of microbial life in ocean crust. Nature 453:653-656.

Schwabe, G.H. (1972) Blue-green algae as pioneers on postvolcanic substrate (Surtsey/Iceland). In Proceedings of the $1^{\text {st }}$ International Symposium of Taxonomy and Biology of Blue-Green Algaes, edited by T.V. Desikachary, University of Madras, Madras, India, pp 419-424.

Stroncik, N.A. and Schmincke, H.U. (2002) Palagonite-a review. International Journal of Earth Sciences 91:680-697.

Thorseth, I.H., Torsvik, T., Torsvik, V., Daae, F.L., Pedersen, R.B., and the Keldysh-98 scientific party. (2001) Diversity of life in ocean floor basalt. Earth Planet Sci Lett 194:31-37.

Venugopalan, T., Sun, T., and Grattan, K.T.V. (2008) Long period grating-based humidity sensor for potential structural health monitoring. Sens Actuators A Phys 148:57-62.

Voronina, V.V. and Horoshenkov, K.V. (2004) Acoustic properties of granular mixes. Applied Acoustics 65:673-691.

Walker, J.J. and Pace, N.R. (2007) Phylogenetic composition of Rocky Mountain endolithic microbial ecosystems. Appl Environ Microbiol 73:3497-3504.

Warren-Rhodes, K.A., Rhodes, K.L., Pointing, S.B., Ewing, S.A., Lacap, D.C., Gomez-Silva, B., Amundson, R., Friedmann, E.I., and McKay, C.P. (2006) Hypolithic cyanobacteria, dry limit of photosynthesis, and microbial ecology in the hyperarid Atacama Desert. Microb Ecol 52:389-398.

Yeo, T.L., Sun, T., and Grattan, K.T.V. (2008) Fibre-optic sensor technologies for humidity and moisture measurement. Sens Actuators A Phys 144:280-295.

Address correspondence to: Elizabeth Bagshaw

Bristol Glaciology Centre

School of Geographical Sciences University Road

University of Bristol Bristol BS8 1SS

UK

E-mail: liz.bagshaw@bristol.ac.uk

Submitted 15 October 2010 Accepted 3 July 2011 
This article has been cited by:

1. Charles S. Cockell, Sherry L. Cady, Nicola McLoughlin . 2011. Introduction: Volcanism and Astrobiology: Life on Earth and Beyond. Astrobiology 11:7, 583-584. [Citation] [Full Text] [PDF] [PDF Plus] 